\title{
The Ac-Trp-DPhe(p-I)-Arg-Trp- $\mathrm{NH}_{2}$ 250-Fold Selective Melanocortin-4 Receptor (MC4R) Antagonist over the Melanocortin-3 Receptor (MC3R) Affects Energy Homeostasis in Male and Female Mice Differently
}

\author{
Cody J. Lensing ${ }^{1}$, Danielle N. Adank ${ }^{1}$, Skye R. Doering ${ }^{1}$, Stacey L. Wilber ${ }^{1}$, Amy \\ Andreasen ${ }^{2}$, Jay W. Schaub ${ }^{2}$, Zhimin Xiang ${ }^{2}$, and Carrie Haskell-Luevano 1,2, ${ }^{\text {* }}$ \\ ${ }^{1}$ Department of Medicinal Chemistry, University of Minnesota, Minneapolis, MN, USA \\ ${ }^{2}$ Department of Pharmacodynamics, College of Pharmacy, University of Florida, Gainesville, FL, \\ USA
}

\begin{abstract}
The melanocortin-4 receptor (MC4R) has been indicated as a therapeutic target for metabolic disorders such as anorexia, cachexia, and obesity. The current study investigates the in vivo effects on energy homeostasis of a $15 \mathrm{nM}$ MC4R antagonist SKY2-23-7, Ac-Trp-DPhe(p-I)-Arg-Trp$\mathrm{NH}_{2}$, that is a 3,700 nM melanocortin-3 receptor (MC3R) antagonist with minimal MC3R and MC4R agonist activity. When monitoring both male and female mice in TSE metabolic cages, sexspecific responses were observed in food intake, respiratory exchange ratio (RER), and energy expenditure. A $7.5 \mathrm{nmol}$ dose of SKY2-23-7 increased food intake, increased RER, and trended towards decreasing energy expenditure in male mice. However, this compound had minimal effect on female mice's food intake and RER at the $7.5 \mathrm{nmol}$ dose. A $2.5 \mathrm{nmol}$ dose of SKY2-23-7 significantly increased female food intake, RER, and energy expenditure while having a minimal effect on male mice at this dose. The observed sex differences of SKY2-23-7 administration result in the discovery of a novel chemical probe for elucidating the molecular mechanisms of the sexual dimorphism present within the melanocortin pathway. To further explore the melanocortin sexual dimorphism, hypothalamic gene expression was examined. The mRNA expression of the MC3R and proopiomelanocortin (POMC) were not significantly different between sexes. However, the expression of agouti-related peptide (AGRP) was significantly higher in female mice which may be a possible mechanism for the sex-specific effects observed with SKY2-23-7.
\end{abstract}

\section{Table of Contents Graphic}

\footnotetext{
*Corresponding Author: chaskell@umn.edu; Phone: 612-626-9262; Fax: 612-626-3114; Street Address: Department of Medicinal Chemistry, University of Minnesota, 308 Harvard Street SE, Minneapolis, MN, 55455, USA.

Author Contributions: C.J.L., D.N.A., and S.L.W. performed animal studies. S.R.D. synthesized and purified the SKY2-23-7. J.W.S. and Z.X. performed the qRT-PCR. C.J.L. wrote the manuscript with contributions from D.N.A, S.R.D. and C.H.L.

Conflict of Interest: The authors declare no competing financial interests.
} 


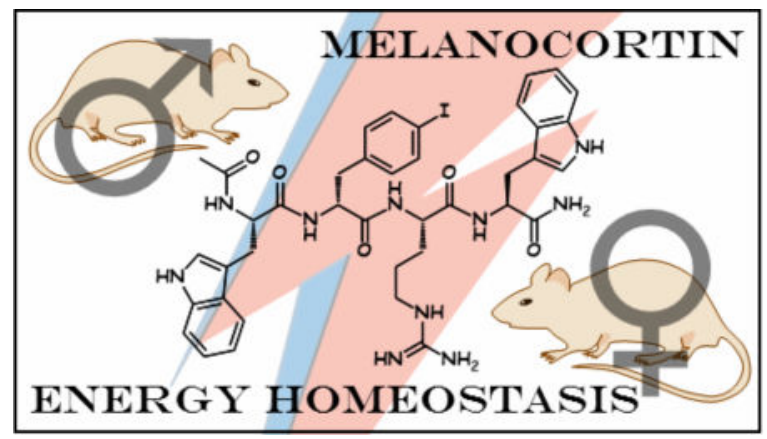

\section{Keywords}

Melanotropin; GPCR; gender differences; sexual dimorphism; sex; a-MSH; TSE cages; gene expression; hypothalamus; RT-PCR

\section{Introduction}

The physiological functions of the melanocortin system include pigmentation, ${ }^{1}$ sexual behavior, ${ }^{2,3}$ blood pressure modulation, ${ }^{4,5}$ and energy homeostasis. ${ }^{6-10}$ The system is comprised of five GPCRs (MC1-5R), proopiomelanocortin (POMC) derived endogenous agonists ( $\alpha$-MSH, $\beta$-MSH, $\gamma$-MSH, ACTH), and antagonists (ASIP, AGRP). ${ }^{1,11}$ Central administration of nonselective MC3R and MC4R agonist ligands result in decreased food intake, and therefore, agonists represent potential therapeutics for metabolic disorders resulting from net positive calorie consumption (e.g. obesity) ${ }^{6-9}$ In contrast, central administration of MC3R and MC4R non-selective antagonist ligands result in increased food intake, and therefore, antagonists represent potential therapeutics for metabolic disorders resulting from a calorie deficit (e.g. cachexia and anorexia). ${ }^{8-10}$ These effects are largely mediated through the MC3R and MC4R located hypothalamus. Intracerebroventricular (ICV) administration of mixed MC3R/MC4R endogenous antagonist/inverse agonist AGRP in both MC3R and MC4R male knockout mice results in increased food intake. ${ }^{8,} 12$ Similarly, administration of mixed MC3R/MC4R agonist melanotan-II (MTII) results in decreased food intake in both MC3R and MC4R knockout mice suggesting both receptors are possible therapeutic targets to regulate satiety and energy homeostasis. However, melanocortin ligands are limited as therapeutics to treat metabolic disorders due to their undesirable effects such as modulating blood pressure ${ }^{4,5}$ and inducing male erections. ${ }^{3}$

Interestingly, there have been several reports of melanocortin ligands having differential effects in males and females including their effects on energy homeostasis, ${ }^{13}$ and cardiovascular regulation. ${ }^{5}$ Sexual dimorphisms related to energy homeostasis were also observed in the initial report of the MC4R knockout mice. ${ }^{14}$ Female MC4R knockout mice were two times heavier as their wild-type counterparts after 15 weeks whereas male MC4R knockout mice were one and a half times heavier than their wildtype counterparts. ${ }^{14}$ However, administration of the MC3R/MC4R agonist MTII to MC3R and MC4R knockout mice was reported to decrease food intake with no differences reported between male and female mice of the same genotype. ${ }^{15}, 16$ In humans, women with a loss of function mutation 
in the MC4R accumulate more body mass compared to men as seen in their body mass index ( $\sim 8-9 \mathrm{~kg} / \mathrm{m}^{2}$ for females vs $\sim 4-5 \mathrm{~kg} / \mathrm{m}^{2}$ for males). ${ }^{17,} 18$

In spite of these reports, and a call by the NIH to increase female subjects in preclinical experiments, ${ }^{19}$ head-to-head comparison of melanocortin ligands' effects on energy homeostasis in males and females are limited. Studies that include males and females primarily focus on well-studied melanocortin ligands such as the endogenous MC3R antagonist and MC4R antagonist/inverse agonist AGRP, ${ }^{13}$ the synthetic antagonist SHU9119 which is a MC3R partial agonist/antagonist and MC4R antagonist, ${ }^{5}$ and synthetic nonselective agonist MTII. ${ }^{20}$ The discovery and development of novel chemical probes that affect male and female energy homeostasis differently are desirable as these would be useful in the elucidation of the sexual dimorphism present in the melanocortin system.

Furthermore, ligands with sex-specific effects may be able to overcome some of the limitations of melanocortin ligands as therapeutics to treat metabolic disorders by targeting exclusively females. For example, females would not possess the inherent erectile inducing side effects observed in males. The undesirable side effect of increasing blood pressure (that has been extensively characterized in males, but not as thoroughly in females) may not be present in females treated with ligands with sex-specific effects, although this would need to be experimentally verified.

It has been reported the MC3R antagonist and MC4R inverse agonist/antagonist AGRP reduces energy expenditure in female rats more than in male rats, although food intake is unaffected. ${ }^{13}$ However, that study has been contradicted by several other reports that found no difference between male and female rodents with melanocortin ligands. ${ }^{15,} 20,21$ To further confound the understanding of the melanocortin ligands' sex-dependent effects, many reports combine both sexes into their results, while others fail to indicate which sex was being studied. There is a need for studies that undertake head-to-head comparison of melanocortin compounds' in vivo effects in both males and females.

In the current study, we report compound SKY2-23-7 (Ac-Trp-DPhe(p-I)-Arg-Trp-NH $\mathrm{N}_{2}$ ) that affects female and male wild type littermate mice differently. ${ }^{22,}{ }^{23}$ Compound SKY2-23-7 was previously identified in our lab. ${ }^{22,23} \mathrm{It}$ is a micromolar antagonist at the mouse (m)MC3R $\left(\mathrm{pA}_{2}=5.43 \pm 0.16, \mathrm{~K}_{\mathrm{i}}=3,700 \mathrm{nM}\right)$ and a nanomolar antagonist at the mMC4R $\left(\mathrm{pA}_{2}\right.$ $=7.83 \pm 0.16, \mathrm{~K}_{\mathrm{i}}=15 \mathrm{nM}$ ). In addition, it possessed minimal agonist activity up to $100 \mu \mathrm{M}$ at both the mMC3R and mMC4R, a pharmacological profile that is not commonly observed for $\mathrm{mMC} 3 \mathrm{R}$ or $\mathrm{mMC} 4 \mathrm{R}$ antagonists (Figure $1 \mathrm{~A}$ and $\mathrm{B}$ ). It was also a micromolar agonist at the $\mathrm{mMC} 1 \mathrm{R}\left(\mathrm{EC}_{50}=2000 \pm 600 \mathrm{nM}\right)$ and at the $\mathrm{mMC} 5 \mathrm{R}\left(\mathrm{EC}_{50}=2800 \pm 1100 \mathrm{nM}\right)$. Synthetic antagonist SHU9119 has been reported on extensively in the literature to competitively antagonize the central melanocortin receptors (i.e. MC3R and MC4R) in vivo, 5, 8, 21, 24 however, these results can be difficult to interpret due to its partial agonism at the mMC3R (50\% at $1 \mu \mathrm{M} ; \mathrm{EC}_{50}=3.0 \pm 0.7 \mathrm{nM}$ ) (Figure $1 \mathrm{C}$ and $\mathrm{D}$ ). It was hypothesized that partial agonism of SHU9119 at the mMC3R may affect its in vivo pharmacology. In order to test this hypothesis, we studied the in vivo effects of SKY2-23-7, which unlike SHU9119, has very limited mMC3R agonism and more selectively antagonizes the mMC4R versus the mMC3R (250-fold). Antagonizing either the mMC3R or the mMC4R is predicted to result in increased food intake based upon the hyperphagia observed when AGRP is administered 
ICV to either MC3R or MC4R knockout mice. ${ }^{8,12}$ In male wild type mice, we observed similar effects on food intake, respiratory exchange ratio (RER), and energy expenditure as those previously reported with SHU9119. Unpredictably, a different pattern was observed in female wildtype littermates.

\section{Results and Discussion ICV Administration Effect on Food Intake}

In the initial pilot studies, SKY2-23-7 was administered intracerebroventricularly (ICV) in parallel to both male and female mice in a conventional nocturnal feeding paradigm. ${ }^{25}$ Both male and female mice were implanted with a cannula into a lateral ventricle through which they received a $5 \mathrm{nmol}$ dose of SKY2-23-7 while housed in "conventional" standard mouse cages. Consistent with SKY2-23-7 acting as an antagonist, similar to SHU9119 or AGRP, an increase in food intake was observed for male mice. However, this trend was not observed in the female mice. In order to better understand this trend more thoroughly, a new cohort of both male and female littermate wildtype mice were cannulated and acclimated to TSE Phenotypic metabolic cages configured to automatically measure food intake, water intake, changes in $\mathrm{CO}_{2}$ and $\mathrm{O}_{2}$, and activity.

Central ICV administration of SKY2-23-7 to mice housed in metabolic cages resulted in a dose dependent increase in food intake in male mice $(\mathrm{p}<0.0001)$. A significant increase in food intake was observed at the $7.5 \mathrm{nmol}$ dose 2-24 hours post-administration (Figure 2A). This result was consistent with the in vitro pharmacology of SKY2-23-7 acting as an mMC4R antagonist. However, parallel ICV administration of SKY2-23-7 to female mice did not result in the same dose response pattern. At the $7.5 \mathrm{nmol}$ and $5 \mathrm{nmol}$ dose, no significant effect was observed in females (Figure 2B). A dose response pattern is observed at the 2.5 $\mathrm{nmol}, 1 \mathrm{nmol}$, and $0.5 \mathrm{nmol}$ doses in females. A significant increase in food intake was observed 6-24 hours post-administration of $2.5 \mathrm{nmols}$ of SKY2-23-7. It was unanticipated that the $7.5 \mathrm{nmol}$ dose that caused the greatest increase in food intake in male mice resulted in no significant differences in female littermates. Additionally, the $2.5 \mathrm{nmol}$ dose that caused the greatest increase in food intake in female mice resulted in no significant effect in the male littermates. The sex-specific dosing pattern suggests that this compound may be affecting female and male mice differently. The binding of SKY2-23-7 to the male or female melanocortin receptors should theoretically be the same as they have the same receptor amino acid sequences, and therefore, the sex-specific effects may be related to sex differences in the expression levels of the melanocortin receptors or signaling molecules.

It is worth noting that the metabolic cage experiments were performed in parallel with littermate male and female mice with the same two researchers (of opposite sexes). This experimental paradigm ensured female and male mice received the same sample preparation of compound for the same doses in the same environment at the same ages. During crossover experiments, female and male mice were split between the compound group and the vehicle group. The crossover paradigm was used for the $7.5 \mathrm{nmol}$ dose, $5 \mathrm{nmol}$ dose, and $2.5 \mathrm{nmol}$ dose. A second $5 \mathrm{nmol}$ dose and the $1.0 \mathrm{nmol}$ and $0.5 \mathrm{nmol}$ doses were performed on both groups simultaneously (Supplemental Information Table 1). This experimental design controls for any environmental factors (room temperature, noise pollution, etc.) that 
may vary slightly between experimental replicates. Controlling for these environmental factors is important because subtle changes in the environment have previously been shown to affect animal behavior. ${ }^{25-28}$

\section{Effect on Respiratory Exchange Ratio}

Melanocortin antagonists, SHU9119 and AGRP, have previously been reported to increase respiratory exchange ratio (RER) suggesting increased utilization of carbohydrates as fuel source or a reduction in fat oxidation. ${ }^{13,24}$ The RER is calculated by dividing the volume of $\mathrm{CO}_{2}$ produced by an animal by the volume of $\mathrm{O}_{2}$ consumed by the animal. ${ }^{29}, 30$ This is calculated indirectly by the measuring the amount of $\mathrm{CO}_{2}$ and $\mathrm{O}_{2}$ entering and exiting the sealed metabolic cages. RER values of c.a. 0.7 indicate that fats are the primary fuel source in the body, whereas an RER values of c.a. 1.0 indicate that carbohydrates are the primary fuel source. ${ }^{29,} 30$ In the current study, a $7.5 \mathrm{nmol}$ dose of antagonist SKY2-23-7 increased the total average RER in male mice during the first two hours following injection and the first dark cycle ( $0-14 \mathrm{hrs})(\mathrm{p}<0.01$; Figure 3A Inset). Since the mice were roused during compound administration, we have included the two hours post administration to be part of the first dark cycle through the current study. The RER was increased at the individual time points 2-7 and 10-14 hours after compound administration (Figure 3A). In the following light cycle (when the mice sleep, 14-26 hrs), the average RER drops most likely due to inactivity and decreased food intake. No significant effect was observed on the total average RER during the entire light cycle (14-26 hrs post administration) in male mice (Figure 3A Inset). However, RER was significantly increased at early hours during the light cycle time points (15-18 hrs post-administration, Figure 3A). In female mice, no effect was observed at the $7.5 \mathrm{nmol}$ dose. Unlike in the male mice, the $2.5 \mathrm{nmol}$ dose of SKY2-23-7 significantly increased the average RER throughout both dark and light cycles in female mice $(\mathrm{p}<0.01$; Figure 3B Inset). Significant effects on RER were observed at 3-7, 9, 13-19, and 21-22 hrs post-administration (Figure 3B). A significant effect on the average RER was observed at the $1.0 \mathrm{nmol}$ dose as well in the dark cycle $(\mathrm{p}<0.05)$. Full time course data of all doses and parameters can be found in the Supplemental Materials.

It is interesting that the dose-specific trend observed in food intake is also observed in the RER. In both sexes, antagonizing the neuronal melanocortin receptors increases RER indicating a shift in the fuel source to carbohydrates which is consistent with previous studies. ${ }^{24}$ However, the dose necessary to achieve a significant physiological effect is smaller in female mice than in male mice. One possibility for the differences in effect may be different neuroanatomy of male and female mice. In our mixed background (C57BL/6J and $129 / \mathrm{Sv}$ ) mouse strain, we do not observe a significant difference in the brain weight of female mice $(490 \pm 15 \mathrm{mg}, \mathrm{n}=17)$ or male mice $(500 \pm 20 \mathrm{mg}, \mathrm{n}=11)$. It has previously been reported that male mice's brains are $2.5 \%$ larger than females, ${ }^{31}$ however females have been reported to have larger lateral ventricles than males $\left(5.15 \mathrm{~mm}^{3}\right.$ versus $\left.3.65 \mathrm{~mm}^{3}\right) .{ }^{32}$ Given the current study's route of administration is ICV, it is possible that in the female mice's $40 \%$ larger lateral ventricle the compound may be diluted more by the cerebrospinal fluid compared to males after receiving the same amount of compound. Therefore, the concentration in the lateral ventricle of SKY2-23-7 could be more dilute in female mice. At the $2.5 \mathrm{nmol}$ dose, the females would be exposed to a lower concentration in the ventricle 
indicating they are more responsive than male mice to SKY2-23-7 at low doses. However, there would also be a lower concentration in females at higher doses, so the neuroanatomy differences do not completely explain the sex-specific dosing pattern observed.

\section{Effect on Energy Expenditure}

Melanocortin antagonists, such as SHU9119 and AGRP, have been reported to decrease energy expenditure. ${ }^{13,24}$ In the current study, a decrease in energy expenditure normalized to weight $(\mathrm{Kcal} / \mathrm{hr} / \mathrm{kg})$ is observed in male mice at 4, 20, 21, 23 and 24 hours after $7.5 \mathrm{nmol}$ administration of SKY2-23-7 compared to control administration (Figure 4A). No significant effect was seen at lower doses. There was no effect observed in the total calories spent in 24 hours after administration in male mice (Figure 4A Inset). In female mice, a significant increase in energy expenditure was observed after a $2.5 \mathrm{nmol}$ administration of SKY2-23-7 ( $<<0.001)$. This effect was observed at 5, 6, 15, 21, and 22 hours post administration (Figure 4B). The total calories burned in 24 hours also increased in a dose dependent manor $(2.5 \mathrm{nmol}>1.0 \mathrm{nmol}>0.5 \mathrm{nmol})$ (Figure 4B Inset). A significant decrease in total calories burned in 24 hours was observed with $7.5 \mathrm{nmol}$ dose of SKY2-23-7 in female mice $(\mathrm{p}<0.05)$.

Considering the effect on food intake and RER were similar, the differences in the effect on energy expenditure observed with the dose that most significantly affected food intake (7.5 $\mathrm{nmol}$ for males and $2.5 \mathrm{nmol}$ for females) suggests that the modulation in the energy expenditure is different in males and females. This result was in contrast to that of Goodin and coworkers who reported a greater reduction in energy expenditure in female rats versus male rats after AGRP administration. ${ }^{13}$ This suggests the effect is compound dependent and that pharmacological probes and potential therapeutics could be developed with specific physiological effects in females versus males. The observation that compounds may have different effects at distinct physiological parameters in female and male mice is also important in experimental design, such that all physiological attributes of a study should be examined in both males and females if comprehensive understanding is desired.

Extrapolating from female mice to male mice or vice versus should only be performed with caution.

\section{Effect on Locomotor Activity}

One hypothesis to explain the observed increased energy expenditure in female mice is increased locomotor activity. Therefore, locomotor activity was quantified by the consecutive infrared beam breaks along the sides of the cage (X-axis). There was no significant effect on the total ambulatory activity (cumulative beam breaks) observed between compound administration and saline administration in male mice in either the dark cycle (0-14 hrs, p=0.39) or light cycle (14-26 hrs, p=0.64) (Figure 5A Inset). There was significant increases in activity observed at individual time points $8,15,18$, and 24 hours post-administration of $7.5 \mathrm{nmol}$ dose of SKY2-23-7 in male mice (Figure 5A). In female mice, there was a significant decrease in total activity at the $5 \mathrm{nmol}$ dose during the light cycle $(\mathrm{p}<0.05)$, but no other doses resulted in a significant changes in total activity in either the dark cycle $(0-14 \mathrm{hrs}, \mathrm{p}=0.28)$ or light cycle $(14-26 \mathrm{hrs}, \mathrm{p}=0.65)$ (Figure 5B Inset). There was significant changes in activity at two individual hour time points. Increased activity was 
observed 5 hours post administration, and a significant decrease in activity was observed at 24 hours post administration in female mice after the $2.5 \mathrm{nmol}$ dose (Figure 5B). The minimal effect on activity at the most active doses in energy expenditure $(7.5 \mathrm{nmol}$ for males and $2.5 \mathrm{nmol}$ for females) suggests that the differences in energy expenditure is not due to variation in ambulatory activity.

Visceral illness could have accounted for the lowered effect of the $7.5 \mathrm{nmol}$ and $5 \mathrm{nmol}$ doses on food intake, RER, and energy expenditure in female mice. Since no changes in activity was observed at the $7.5 \mathrm{nmol}$ dose, it suggests that visceral illness was not the cause of the observed dose differences between male and female mice. Regardless, visceral illness at the higher doses would not explain why the $2.5 \mathrm{nmol}$ dose caused a significant effect in female mice, but had minimal effect in male mice.

A common assumption in the field is that due to the estrus cycle, female mice are more variable than male mice. This variability may make interpretation of female results difficult. However, an extensive analysis of the literature by Prendergast and coworkers indicated that regularly cycling female mice are no more variable than male mice in preclinical studies. ${ }^{33}$ Furthermore, it has previously been observed that ovariectomy or estradiol treatment has minimal effects on food intake after SHU9119 or AGRP treatment suggesting the estrus cycle does not significantly affect antagonizing the central melanocortin receptors. ${ }^{13}, 21,34$ However, these previous studies' results may be confounded by studies reporting that ovariectomy can blunt AGRP -dependent effects on energy expenditure in females ${ }^{13}$ and that estradiol modulates the neuronal melanocortin system. ${ }^{3536}$ These confounding observations call for head-to-head comparison studies of male and normally cycling female mice for future comparison. Additionally, the current study controls for the variability of the estrus cycle's effects by utilizing a crossover paradigm.

\section{Hypothalamic Melanocortin Pathway Gene Expression}

The observed sex-specific differences of SKY-2-23-7 validates it as a molecular probe to understand the reported, but confounding, melanocortin sex-specific effects. $5,13,14,17,18$ The exact mechanism of the sex-specific effects of SKY2-23-7 is still unclear, but it likely arises from two aspects: 1) The unique in vitro pharmacology of SKY-2-23-7. Compared to other commonly studied antagonists such as SHU9119 or AGRP, SKY2-23-7 has minimal MC3R agonism and more selectively antagonizes the MC4R versus the MC3R (250-fold). It is also a weaker antagonist than SHU9119 or AGRP. 2) And how this unique pharmacological profile influences the sexual dimorphism present in the complex melanocortin signaling pathways within the brain.

Measurement of mRNA in the hypothalamus by qRT-PCR may provide mechanistic information to better examine sex differences within the melanocortin signaling pathway. Previous unpublished results in our laboratory examined hypothalamic mRNA expression of the MC3R, POMC, and AGRP genes in the current mouse strain (Figure 6). ${ }^{37}$ Unfortunately, the relative MC4R expression profiles between male and female mice was not studied at the time the MC3R, POMC, and AGRP expression was investigated in our laboratory, ${ }^{37}$ and hence is not included in this report but will be examined in the future. However, it has been previously reported that the MC4R is differentially expressed some regions of the brain 
(including the hypothalamus) of male and estrous female rats and that the MC4R is more highly expressed in the hypothalamus of female than male $\mathrm{C} 57 \mathrm{Bl} / 6 \mathrm{~J}$ mice. ${ }^{38,} 39$ Unexpectedly, in our mouse strain the mRNA expression levels of AGRP was observed to be significantly higher in female mice than in male mice $(\mathrm{p}<0.05)$. No statistically significant differences were observed between male and female mice for MC3R and POMC hypothalamic mRNA expression levels. ${ }^{37}$

The increase in AGRP expression suggests that more endogenous AGRP is necessary to maintain baseline feeding patterns in females than in males. It may then follow that at lower concentrations of SKY2-23-7 in females, the ligand functions as a typical antagonist competing with endogenous POMC derived agonist peptides (i.e. a-MSH, $\beta$-MSH, $\gamma$-MSH, ACTH) to increase feeding. However, at high concentrations the weaker antagonist SKY2-23-7 (mMC4R $\mathrm{K}_{\mathrm{i}}=14.8 \mathrm{nM} ; \mathrm{pA}_{2}=7.83$ ) may compete for binding with the more potent antagonist/inverse agonist AGRP $\left(\mathrm{mMC} 4 \mathrm{R} \mathrm{K}_{\mathrm{i}}=0.40-2.5 \mathrm{nM} ; \mathrm{pA}_{2}=9.4\right){ }^{40,41}$ Because SKY2-23-7 would be competing off a more potent antagonist, it would be "functionally antagonizing" the endogenous antagonist/inverse agonist effects of AGRP which would reduce the ability of AGRP to maintain normal baseline feeding. The lowered baseline effect of endogenous AGRP would result in lowered increases in food intake and physiological effects than that observed at lower doses of SKY2-23-7.

This hypothesis is consistent with the bell-shaped doses response curve observed currently in female mice in food intake (Figure 2B), RER, (Figure 3B), and energy expenditure (Figure 4B). Female male mice would be more sensitive to this effect since they have more baseline signaling of AGRP than male mice. It would be postulated that a similar bellshaped dose response would be observed at higher doses of SKY-2-23-7 in male mice, however, higher dosing was prevented due to the solubility of SKY2-23-7. Also this effect would not be seen with more potent antagonists (e.g. SHU9119 and AGRP) because they would be potent enough to maintain baseline feeding patterns of the when displacing endogenous AGRP.

This is just one possible hypothesis for the sex-specific effects observed currently. There are other possibilities including expression of the receptors and ligands in particular regions of the hypothalamus, differences in connectivity of the neurons expressing the receptors, or from downstream signaling pathways of the melanocortin receptors. For example, as mentioned above it has been previously reported that the MC4R is differentially expressed in the brain of male and female rodents. ${ }^{38,39}$ However, if receptor differences were the principle cause of the sex-specific effects observed with SKY-2-23-7, it would be unclear why other antagonist ligands (such as AGRP and SHU9119) would not have consistently reported sex-specific effects. Also the bell shaped dose response would be difficult to explain. The current study provides the field with a molecular probe for future elucidation and design of more chemical probes with sex-specific effects for further elucidation of the melanocortin sexual dimorphism. 


\section{Conclusions}

There is currently no technology capable of correlating melanocortin ligands with sex differences in vitro. In order to develop in vitro assays that can model and predict in vivo sex-specific effects of melanocortin ligands, chemical probes with known in vivo sex differences, such as currently reported SKY2-23-7, will be essential to confirm and validate an in vitro assay's ability to accurately predict sex-specific effects. The current report suggests melanocortin ligands can be designed to have different physiological effects in males and females. The opposing result of SKY2-23-7 on energy expenditure leads to the hypothesis that melanocortin ligands could potentially have sex-specific consequences on other physiological effects such as melanocortin-dependent modulation of blood pressure. ${ }^{4,5}$ It could be hypothesized that an agonist compound with the ability to decrease food intake in both male and female (albeit at different doses) might be able to modulate the effect on blood pressure differently between sexes. This may lead to melanocortin ligands that therapeutically target only females in which the hypothesized agonist decreases food intake without any cardiovascular effects. In support of this hypothesis, Maranon and coworkers in 2014 observed ICV administration of SHU9119 significantly reduced blood pressure in male rats, but had no effect on blood pressure in female rats. ${ }^{5}$ Furthermore, a clinical trial in 2008 studying arousal disorder in females reported no clinically significant effects on blood pressure or heart rate in 40 premenopausal women after MC4R agonist administration. ${ }^{2}$ The current report provides the field with a novel chemical probe for studying the sexual dimorphism present within the melanocortin pathway. Furthermore, the current ligand gives a starting point for the design of more melanocortin ligands with sex-specific effects. Designing ligands with sex-specific effects, such as SKY2-23-7, could be a new approach to overcome the limitations known to melanocortin ligands as therapeutics for the treatment of metabolic disorders.

\section{Methods}

\section{Peptide Preparation}

Compound SKY2-23-7 utilized in this study was synthesized as previously reported using standard Fmoc methodology on solid support. ${ }^{22}$ All compounds were purified to greater than 95\% purity by RP-HPLC and mass was determined by ESI-MS. SKY2-23-7 was dissolved in DMSO and diluted to the appropriate concentration in Mill-Q autoclaved water. A matched DMSO vehicle was made of each concentration. The $7.5 \mathrm{nmol}, 5 \mathrm{nmol}, 2.5 \mathrm{nmol}$, $1.0 \mathrm{nmol}$, and $0.5 \mathrm{nmol}$ vehicles contained $0.72 \%, 0.48 \%, 0.24 \%, 0.096 \%$, and $0.048 \%$ DMSO, respectively. SKY2-23-7 precipitated out whenever it was added to saline alone. Also SKY2-23-7 precipitates out of solution when frozen in water, therefore, dilutions with water were performed the morning of the assay from the stored DMSO stock. In order to control for any solubility issues, the male and female mice were administered same doses of compound from the same dilution in parallel.

\section{Animals}

All experiments were performed in accordance with the Institutional Animal Care and Use Committee (IACUC) at the University of Minnesota. The mice utilized were wild type 
female and male littermates with mixed genetic background from C57BL/6J and 129/Sv inbred strains. Mice were 8 weeks old at the beginning of the experiment. All mice were housed individually after surgeries and for the remainder of the experiment. Mice were maintained on a $12 \mathrm{hr} \mathrm{light/dark} \mathrm{cycle} \mathrm{(Lights} \mathrm{off} \mathrm{was} \mathrm{at} \mathrm{11:00} \mathrm{AM)} \mathrm{in} \mathrm{a} \mathrm{temperature}$ controlled room $\left(23-25^{\circ} \mathrm{C}\right)$ with free access to normal chow (Harlan Teklad 2018 Diet: $18.6 \%$ crude protein, $6.2 \%$ crude fat, $3.5 \%$ crude fiber, with energy density of $3.1 \mathrm{kcal} / \mathrm{g}$ ) and tap water. Preliminary conventional cage studies and hPYY validation studies were performed in standard mouse polycarbonate conventional cages provided by University of Minnesota's Research Animal Resources (RAR). Weekly cage changes were conducted by lab research staff.

\section{Cannulation Surgery and Placement Validation}

Surgeries were performed to place a cannula in the lateral cerebral ventricle as previously reported. ${ }^{7,8}$ A mixture of ketamine $(100 \mathrm{mg} / \mathrm{kg}$ ) and xylazine $(5 \mathrm{mg} / \mathrm{kg})$ was used to anesthetize the mice. They were then positioned in a stereotaxic apparatus (David Kopf Instruments). The 26-gauge cannula (Cat\# 8IC315GS4SPC; PlasticsOne, Roanoke, VA) was inserted in the lateral cerebral ventricle at the coordinates $1.0 \mathrm{~mm}$ lateral and $0.46 \mathrm{~mm}$ posterior to bregma and $2.3 \mathrm{~mm}$ ventral to the skull. ${ }^{42}$ The cannula was secured to the skull using n-butyl cyanoacrylate glue (3M Vetbond) and dental cement (Jet Dental and Fleck's Zinc). A post-surgery dose of flunixin meglumine (FluMegluine, Clipper Distribution Company) and $0.5 \mathrm{~mL}$ of $0.9 \%$ saline (Hospira, Lake Forrest, IL) subcutaneously was given to help recovery. All mice were given at least seven days to recover from surgery before cannula placement validation.

The placement of the cannula was verified by the feeding response after ICV administration of $2.5 \mu \mathrm{g}$ of human (h)PYY $\mathrm{PY}_{36}$ (Bachem) as described previously. ${ }^{6-8}$ Each mouse was administered hPYY and saline on different days following a crossover design. Mice were given at least four days between administration to ensure that normal feeding patterns and body weight returned. Food intake and body weight was manually measured 2, 4, 6, 24 hours after hPYY or saline administration. A mouse with a verified cannula consumed at least $0.9 \mathrm{~g}$ more after hPYY administration compared to saline administration 4 hours postadministration. Validated female mice on average ate $0.29 \pm 0.08 \mathrm{~g}$ of food four hours after saline administration and $1.79 \pm 0.15 \mathrm{~g}$ of food four hours after hPYY administration. Male mice on average ate $0.53 \pm 0.07 \mathrm{~g}$ of food four hours after saline administration and 1.89 $\pm 0.10 \mathrm{~g}$ of food four hours after hPYY administration.

\section{SKY2-23-7 Infusion and Energy Metabolism Studies}

Cannulated validated mice were transitioned into TSE PhenoMaster metabolic cages (TSE Systems, Berlin Germany). After a one week acclimation period, male and female mice body weights were $27.1 \pm 0.3 \mathrm{~g}$ and $23.1 \pm 0.5 \mathrm{~g}$, respectively. Following the acclimation period, the indicated amount of SKY 2-23-7 was delivered two hours prior to lights out $(\mathrm{t}=0$ $\mathrm{hr}$ ) through the implanted cannula in a satiated nocturnal paradigm. ${ }^{25}$ Compound was administered in $3 \mu \mathrm{L}$ of vehicle using an infusion internal cannula (Cat\# 8IC315IS4SPC; PlasticsOne, Roanoke, VA). The $7.5 \mathrm{nmol}, 2.5 \mathrm{nmol}$ and first $5 \mathrm{nmol}$ doses followed a crossover design allowing at least a 6-7 days between each administrations (Supp Table 1). After 
which, the $5 \mathrm{nmol}$ dose was repeated on all animals to ensure reproducibility of results. The 1.0 and $0.5 \mathrm{nmol}$ doses were performed on both groups simultaneous (Supp Table 1). Food and water were provided $a b$ libitum throughout the experiment. More details about the exclusion criteria and TSE PhenoMaster data recording and analysis can be found in the Supplemental Materials.

\section{Quantitative real-time polymerase chain reaction (qRT-PCR)}

The quantification of hypothalamic gene expression of 13 week old naïve male and female mice was performed as previously described. ${ }^{43}$ Briefly, male and female mice were sacrificed on the same day (males from 8:00 to 11:00; females from 13:30-15:30). After decapitation, the brain was dissected out and placed immediately in RNALater (Ambion Inc., Austin RX, USA) at $4^{\circ} \mathrm{C}$ for $24 \mathrm{hrs}$, and then stored at $-20^{\circ} \mathrm{C}$ until RNA extraction. Total RNA was extracted with Trizol ${ }^{\circledR}$ method according to the manufactures instructions (Invitrogen, Cat\# 15596-018). The RNA quantified using a NanoDrop ND-1000 and the integrity was verified by gel electrophoresis on $1 \%$ agarose gel. Complementary strand DNA (cDNA) was synthesized using a High Capacity cDNA Archie Kit (Applied Biosystems, Cat \# 4322171) according to manufactures instructions.

The qRT-PCR reactions were performed using $50 \mathrm{ng}$ of cDNA sample with Taqman primers and reagents in an ABI 7300 System (Applied Biosystems). The samples were run on a single 96-well plate in duplicate for each gene probe. The Hprt1 gene was used as a housekeeping gene for data normalization across groups. The male mRNA expression was normalized to 1.0 and the female expression level was expressed as a fold difference compared to male expression. The fold difference was calculated as $2^{-\Delta \Delta \mathrm{Ct}}$, where $\Delta \mathrm{Ct}=$ $\mathrm{Ct}($ gene $)-\mathrm{Ct}($ Hprt1 gene $)$ and $\Delta \Delta \mathrm{Ct}=\Delta \mathrm{Ct}($ Individual Mouse $)-($ Average $\Delta \mathrm{Ct}(\mathrm{WT}$ Conv $))$. Statistical analysis was performed using the $\Delta \mathrm{Ct}$ values. The threshold cycle $(\mathrm{Ct})$ was designated as the PCR cycle where fluorescent signal associated with the gene copy number exceeds the threshold of $10 \times$ noise level.

\section{Statistics}

Data was analyzed using GraphPad 4.0 PRISM software (San Diego, CA). First a regular two-way ANOVA (no matching) was used to show differences between treatment groups over time. Then individual time points were compared by a one-way ANOVA followed by a Bonferroni posttest. All results are presented as mean \pm SEM. Statistical significance was defined as $* \mathrm{p}<0.05, * * \mathrm{p}<0.01, * * * \mathrm{p}<0.001$.

\section{Supporting Information}

Exclusion Criteria (S1) TSE PhenoMaster Data Recording (S1-2) Male and Female Mice RER after SKY2-23-7 ICV Administration (All doses) (S2), Male and Female Mice Energy Expenditure after SKY2-23-7 ICV Administration (All doses)(S3), Male and Female Mice Activity after SKY2-23-7 ICV Administration (All doses)(S3), Latin- Square (crossover) feeding (S4) 


\section{Supplementary Material}

Refer to Web version on PubMed Central for supplementary material.

\section{Acknowledgments}

Funding: This work has been supported by NIH Grant R01DK091906 (CHL).

We would like to thank Sathya Schnell, Katie Schlasner, Katie Freeman, Katlyn Fleming, Dr. Mark Ericson, Dr. Srinivasa Tala, and Dr. Anamika Singh for their insightful dialogue while preparing this manuscript.

\section{Abbreviations}

$\begin{array}{ll}\text { GPCR } & \text { G protein-coupled receptor } \\ \text { AGRP } & \text { Agouti-related peptide } \\ \text { BMI } & \text { body mass index } \\ \text { POMC } & \text { Pro-opiomelanocortin } \\ \text { RP-HPLC } & \text { reverse-phase high-pressure liquid chromatography } \\ \text { ESI-MS } & \text { electron-spray ionization mass spectrometry } \\ \text { DMSO } & \text { dimethyl sulfoxide }\end{array}$

\section{References}

1. Mountjoy KG, Robbins LS, Mortrud MT, Cone RD. The cloning of a family of genes that encode the melanocortin receptors. Science. 1992; 257:1248-1251. [PubMed: 1325670]

2. Safarinejad MR. Evaluation of the safety and efficacy of bremelanotide, a melanocortin receptor agonist, in female subjects with arousal disorder: A double-blind placebo-controlled, fixed dose, randomized study. J. Sex. Med. 2008; 5:887-897. [PubMed: 18179455]

3. Uckert S, Bannowsky A, Albrecht K, Kuczyk MA. Melanocortin receptor agonists in the treatment of male and female sexual dysfunctions: results from basic research and clinical studies. Expert Opin. Invest. Drugs. 2014; 23:1477-1483.

4. Greenfield JR, Miller JW, Keogh JM, Henning E, Satterwhite JH, Cameron GS, Astruc B, Mayer JP, Brage S, See TC, Lomas DJ, O'Rahilly S, Farooqi IS. Modulation of blood pressure by central melanocortinergic pathways. N. Engl. J. Med. 2009; 360:44-52. [PubMed: 19092146]

5. Maranon RO, Lima R, Mathbout M, do Carmo JM, Hall JE, Roman RJ, Reckelhoff JF. Postmenopausal hypertension: role of the sympathetic nervous system in an animal model. Am J Physiol-Reg I. 2014; 306:R248-R256.

6. Marsh DJ, Hollopeter G, Huszar D, Laufer R, Yagaloff KA, Fisher SL, Burn P, Palmiter RD. Response of melanocortin-4 receptor-deficient mice to anorectic and orexigenic peptides. Nat. Genet. 1999; 21:119-122. [PubMed: 9916804]

7. Lensing CJ, Freeman KT, Schnell SM, Adank DN, Speth RC, Haskell-Luevano C. An in Vitro and in Vivo Investigation of Bivalent Ligands That Display Preferential Binding and Functional Activity for Different Melanocortin Receptor Homodimers. J. Med. Chem. 2016; 59:3112-3128. [PubMed: 26959173]

8. Irani BG, Xiang Z, Yarandi HN, Holder JR, Moore MC, Bauzo RM, Proneth B, Shaw AM, Millard WJ, Chambers JB, Benoit SC, Clegg DJ, Haskell-Luevano C. Implication of the melanocortin-3 receptor in the regulation of food intake. Eur. J. Pharmacol. 2011; 660:80-87. [PubMed: 21199647]

9. Fan W, Boston BA, Kesterson RA, Hruby VJ, Cone RD. Role of melanocortinergic neurons in feeding and the agouti obesity syndrome. Nature. 1997; 385:165-168. [PubMed: 8990120] 
10. Joppa MA, Ling N, Chen C, Gogas KR, Foster AC, Markison S. Central administration of peptide and small molecule MC4 receptor antagonists induce hyperphagia in mice and attenuate cytokineinduced anorexia. Peptides. 2005; 26:2294-2301. [PubMed: 16269355]

11. Roselli-Rehfuss L, Mountjoy KG, Robbins LS, Mortrud MT, Low MJ, Tatro JB, Entwistle ML, Simerly RB, Cone RD. Identification of a receptor for gamma melanotropin and other proopiomelanocortin peptides in the hypothalamus and limbic system. Proc. Natl. Acad. Sci. U. S. A. 1993; 90:8856-8860. [PubMed: 8415620]

12. Marsh DJ, Miura GI, Yagaloff KA, Schwartz MW, Barsh GS, Palmiter RD. Effects of neuropeptide $\mathrm{Y}$ deficiency on hypothalamic agouti-related protein expression and responsiveness to melanocortin analogues. Brain Res. 1999; 848:66-77. [PubMed: 10612698]

13. Goodin SZ, Keichler AR, Smith M, Wendt D, Strader AD. Effect of gonadectomy on AgRPinduced weight gain in rats. Am J Physiol-Reg I. 2008; 295:R1747-R1753.

14. Huszar D, Lynch CA, Fairchild-Huntress V, Dunmore JH, Fang Q, Berkemeier LR, Gu W, Kesterson RA, Boston BA, Cone RD, Smith FJ, Campfield LA, Burn P, Lee F. Targeted disruption of the melanocortin-4 receptor results in obesity in mice. Cell. 1997; 88:131-141. [PubMed: 9019399]

15. Rowland NE, Schaub JW, Robertson KL, Andreasen A, Haskell-Luevano C. Effect of MTII on food intake and brain c-Fos in melanocortin-3, melanocortin-4, and double MC3 and MC4 receptor knockout mice. Peptides. 2010; 31:2314-2317. [PubMed: 20800636]

16. Atalayer D, Robertson KL, Haskell-Luevano C, Andreasen A, Rowland NE. Food demand and meal size in mice with single or combined disruption of melanocortin type 3 and 4 receptors. Am. J. Physiol. Regul. Integr. Comp. Physiol. 2010; 298:R1667-1674. [PubMed: 20375267]

17. Dempfle A, Hinney A, Heinzel-Gutenbrunner M, Raab M, Geller F, Gudermann T, Schafer H, Hebebrand J. Large quantitative effect of melanocortin-4 receptor gene mutations on body mass index. J. Med. Genet. 2004; 41:795-800. [PubMed: 15466016]

18. Stutzmann F, Tan K, Vatin V, Dina C, Jouret B, Tichet J, Balkau B, Potoczna N, Horber F, O'Rahilly S, Farooqi IS, Froguel P, Meyre D. Prevalence of melanocortin-4 receptor deficiency in Europeans and their age-dependent penetrance in multigenerational pedigrees. Diabetes. 2008; 57:2511-2518. [PubMed: 18559663]

19. Clayton JA, Collins FS. NIH to balance sex in cell and animal studies. Nature. 2014; 509:282-283. [PubMed: 24834516]

20. Clegg DJ, Riedy CA, Smith KAB, Benoit SC, Woods SC. Differential sensitivity to central leptin and insulin in male and female rats. Diabetes. 2003; 52:682-687. [PubMed: 12606509]

21. Polidori C, Geary N. Estradiol treatment fails to affect the feeding responses to melanocortin-3/4 receptor agonism or antagonism in ovariectomized rats. Peptides. 2002; 23:1697-1700. [PubMed: 12217431]

22. Doering SR, Todorovic A, Haskell-Luevano C. Melanocortin antagonist tetrapeptides with minimal agonist activity at the mouse melanocortin-3 receptor. ACS Med. Chem. Lett. 2015; 6:123-127. [PubMed: 25699138]

23. Lensing CJ, Doering SR, Danielle NA, Haskell-Luevano C. Investigating Metabolic Gender Differences with Melanocortin Antagonist SKY 2-23-7. Proceedings of the 24th American Peptide Symposium. 2015; 24:162-164.

24. Kooijman S, Boon MR, Parlevliet ET, Geerling JJ, van de Pol V, Romijn JA, Havekes LM, Meurs I, Rensen PCN. Inhibition of the central melanocortin system decreases brown adipose tissue activity. J. Lipid Res. 2014; 55:2022-2032. [PubMed: 25016380]

25. Ellacott KL, Morton GJ, Woods SC, Tso P, Schwartz MW. Assessment of feeding behavior in laboratory mice. Cell Metab. 2010; 12:10-17. [PubMed: 20620991]

26. Batterham RL, Cowley MA, Small CJ, Herzog H, Cohen MA, Dakin CL, Wren AM, Brynes AE, Low MJ, Ghatei MA, Cone RD, Bloom SR. Does gut hormone PYY3-36 decrease food intake in rodents? Reply. Nature. 2004; 430

27. Tschop M, Castaneda TR, Joost HG, Thone-Reineke C, Ortmann S, Klaus S, Hagan MM, Chandler PC, Oswald KD, Benoit SC, Seeley RJ, Kinzig KP, Moran TH, Beck-Sickinger AG, Koglin N, Rodgers RJ, Blundell JE, Ishii Y, Beattie AH, Holch P, Allison DB, Raun K, Madsen K, Wulff BS, Stidsen CE, Birringer M, Kreuzer OJ, Schindler M, Arndt K, Rudolf K, Mark M, Deng 
XY, Withcomb DC, Halem H, Taylor J, Dong J, Datta R, Culler M, Craney S, Flora D, Smiley D, Heiman ML. Physiology: Does gut hormone PYY3-36 decrease food intake in rodents? Nature. 2004; 430

28. Sorge RE, Martin LJ, Isbester KA, Sotocinal SG, Rosen S, Tuttle AH, Wieskopf JS, Acland EL, Dokova A, Kadoura B, Leger P, Mapplebeck JC, McPhail M, Delaney A, Wigerblad G, Schumann AP, Quinn T, Frasnelli J, Svensson CI, Sternberg WF, Mogil JS. Olfactory exposure to males, including men, causes stress and related analgesia in rodents. Nat. Methods. 2014; 11:629-632. [PubMed: 24776635]

29. Speakman JR. Measuring energy metabolism in the mouse - theoretical, practical, and analytical considerations. Front. Physiol. 2013; 4:34. [PubMed: 23504620]

30. Meyer CW, Reitmeir P, Tschop MH. Exploration of Energy Metabolism in the Mouse Using Indirect Calorimetry: Measurement of Daily Energy Expenditure (DEE) and Basal Metabolic Rate (BMR). Curr. Protoc. Mouse Biol. 2015; 5:205-222. [PubMed: 26331756]

31. Spring S, Lerch JP, Henkelman RM. Sexual dimorphism revealed in the structure of the mouse brain using three-dimensional magnetic resonance imaging. Neuroimage. 2007; 35:1424-1433. [PubMed: 17408971]

32. Koshibu K, Levitt P, Ahrens ET. Sex-specific, postpuberty changes in mouse brain structures revealed by three-dimensional magnetic resonance microscopy. Neuroimage. 2004; 22:1636-1645. [PubMed: 15275920]

33. Prendergast BJ, Onishi KG, Zucker I. Female mice liberated for inclusion in neuroscience and biomedical research. Neurosci. Biobehav. Rev. 2014; 40:1-5. [PubMed: 24456941]

34. Santollo J, Eckel LA. Estradiol decreases the orexigenic effect of neuropeptide Y, but not agoutirelated protein, in ovariectomized rats. Behav. Brain Res. 2008; 191:173-177. [PubMed: 18453005]

35. Olofsson LE, Pierce AA, Xu AW. Functional requirement of AgRP and NPY neurons in ovarian cycle-dependent regulation of food intake. Proc. Natl. Acad. Sci. U. S. A. 2009; 106:1593215937. [PubMed: 19805233]

36. Gao Q, Mezei G, Nie Y, Rao Y, Choi CS, Bechmann I, Leranth C, Toran-Allerand D, Priest CA, Roberts JL, Gao XB, Mobbs C, Shulman GI, Diano S, Horvath TL. Anorectic estrogen mimics leptin's effect on the rewiring of melanocortin cells and Stat 3 signaling in obese animals. Nat. Med. 2007; 13:89-94. [PubMed: 17195839]

37. Schaub, J. Ph.D. Thesis. University Of Florida; 2011. Effects of voluntary exercise on the central melanocortin receptor knockout mice.

38. Qu HE, Li JP, Chen W, Li YM, Jiang Q, Jiang HZ, Huo JL, Zhao ZH, Liu B, Zhang QL. Differential expression of the melanocortin-4 receptor in male and female C57BL/6J mice. Mol. Biol. Rep. 2014; 41:3245-3256. [PubMed: 24488261]

39. Gelez H, Poirier S, Facchinetti P, Allers KA, Wayman C, Bernabe J, Alexandre L, Giuliano F. Neuroanatomical distribution of the melanocortin-4 receptors in male and female rodent brain. $\mathrm{J}$. Chem. Neuroanat. 2010; 40:310-324. [PubMed: 20884347]

40. Yang YK, Thompson DA, Dickinson CJ, Wilken J, Barsh GS, Kent SB, Gantz I. Characterization of Agouti-related protein binding to melanocortin receptors. Mol. Endocrinol. 1999; 13:148-155. [PubMed: 9892020]

41. Ericson MD, Wilczynski A, Sorensen NB, Xiang Z, Haskell-Luevano C. Discovery of a betaHairpin Octapeptide, c[Pro-Arg-Phe-Phe-Dap-Ala-Phe-DPro], Mimetic of Agouti-Related Protein(87-132) [AGRP(87-132)] with Equipotent Mouse Melanocortin-4 Receptor (mMC4R) Antagonist Pharmacology. J. Med. Chem. 2015; 58:4638-4647. [PubMed: 25898270]

42. Franklin, KBJ., Paxinos, G. The Mouse Brain in Stereotaxic Coordinates. Academic Press; San Diego: 1997.

43. Haskell-Luevano C, Schaub JW, Andreasen A, Haskell KR, Moore MC, Koerper LM, Rouzaud F, Baker HV, Millard WJ, Walter G, Litherland SA, Xiang Z. Voluntary exercise prevents the obese and diabetic metabolic syndrome of the melanocortin-4 receptor knockout mouse. FASEB J. 2009; 23:642-655. [PubMed: 18971258] 


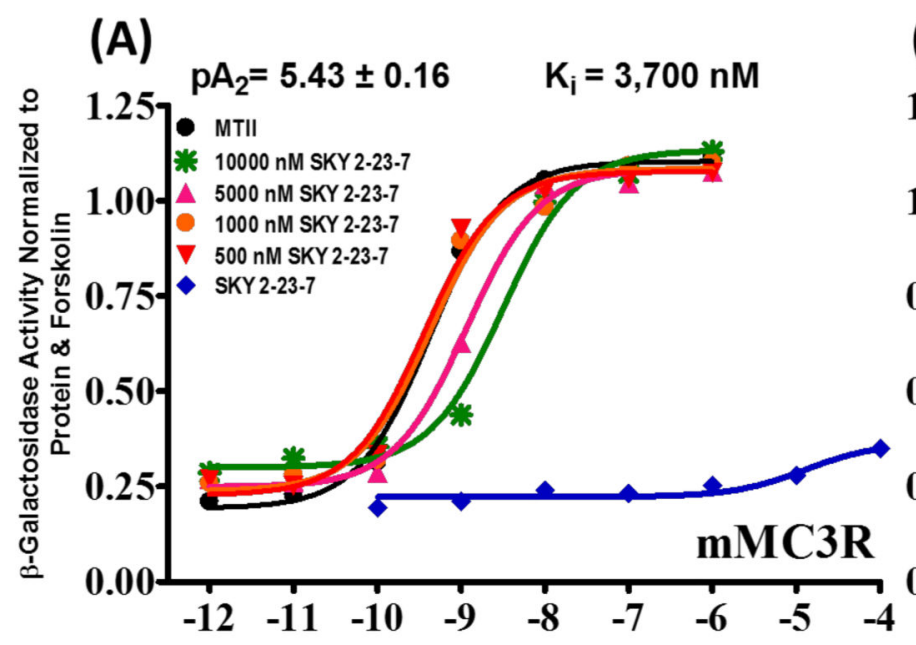

(C) Log Peptide Conc (M)

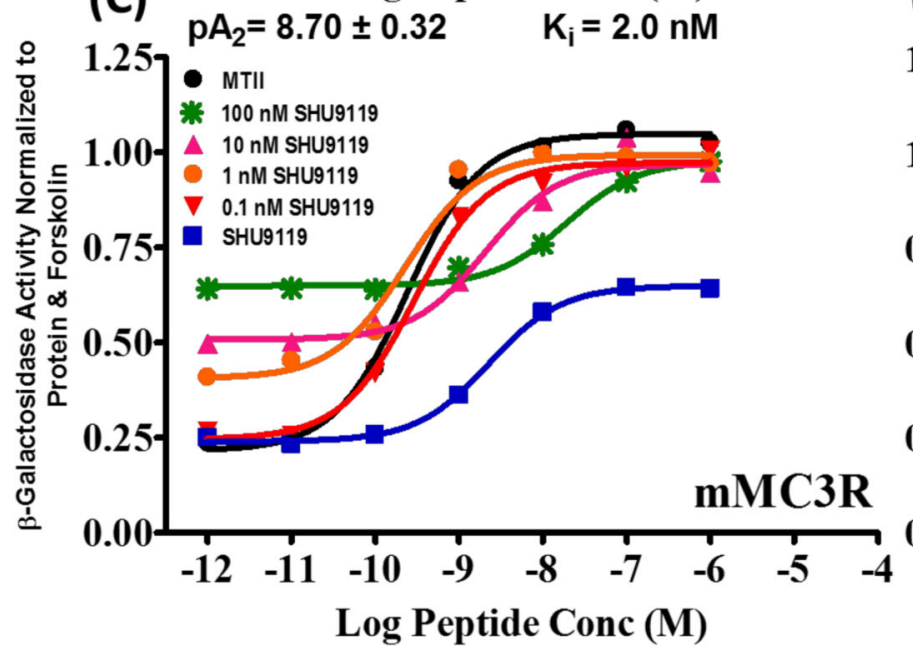

(B)

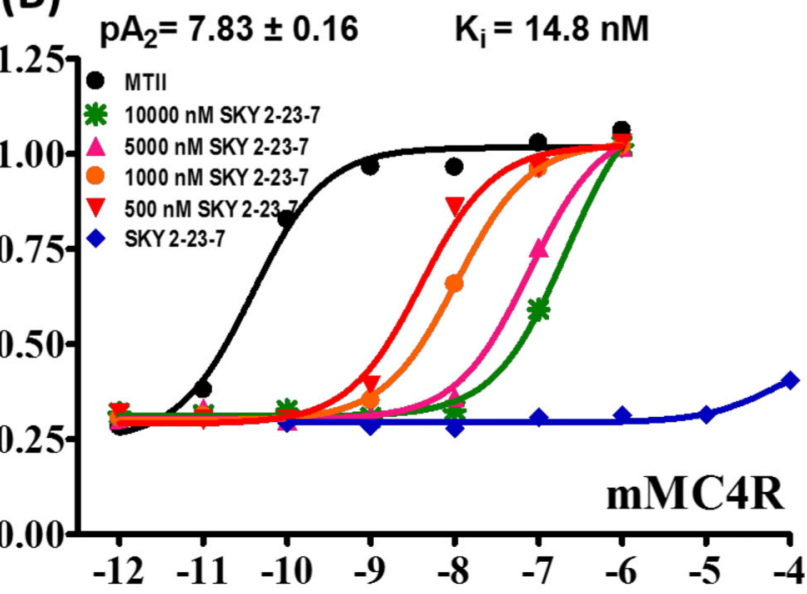

(D)

Log Peptide Conc (M)

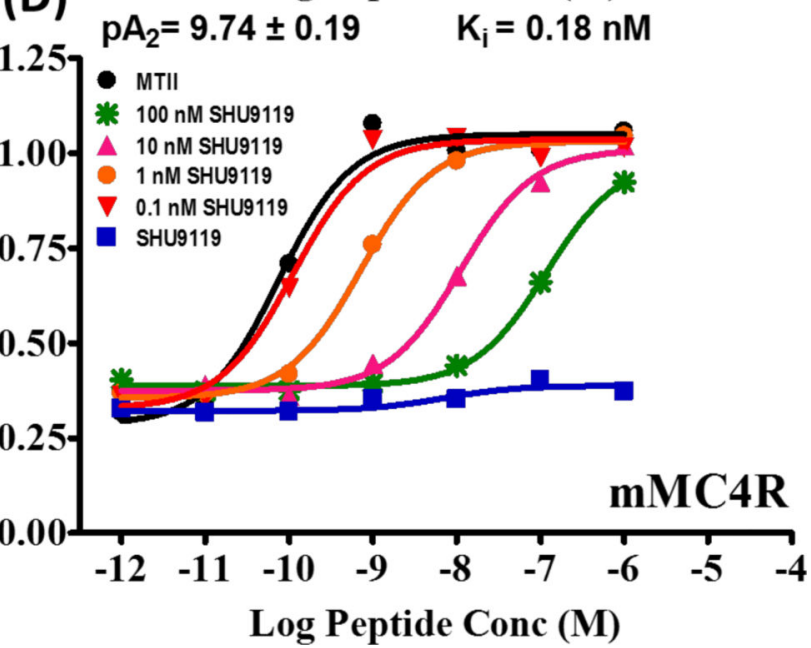

Figure 1.

In vitro pharmacology of SKY2-23-7 versus SHU9119 in female HEK293 cells. A Schild analysis of SKY2-23-7 at the mMC3R (A) and mMC4R (B). A Schild analysis of SHU9119 at the mMC3R (C) and mMC4R (D). SKY2-23-7 lacks the mMC3R partial agonism commonly seen with known central antagonists such as SHU9119 (A versus C). Data from Doering et. $a l^{22}$ 
(A)

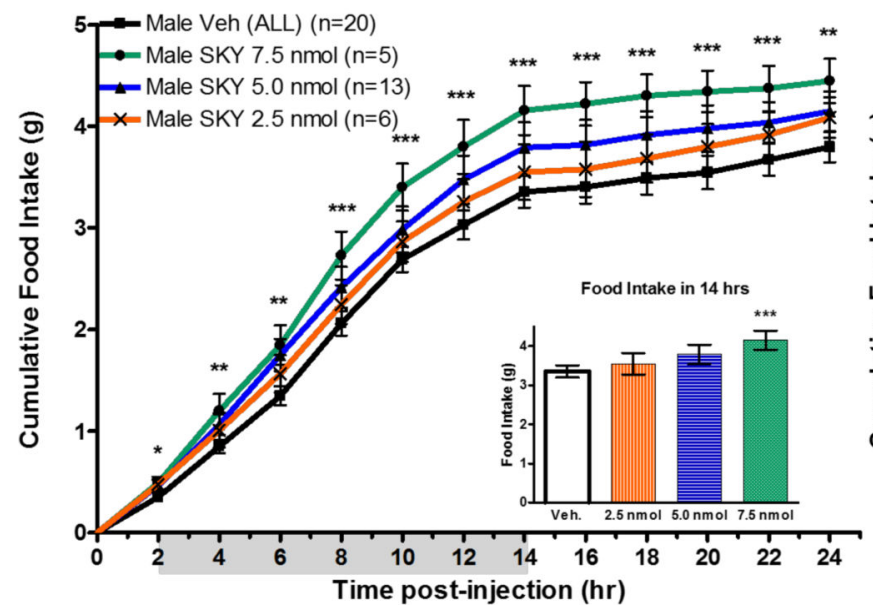

(B)

\section{Female Food Intake}

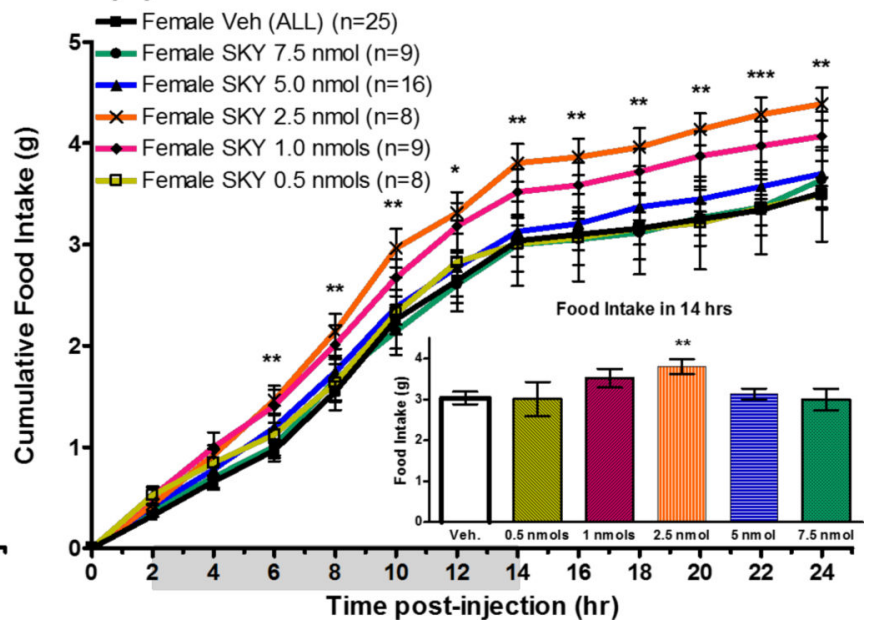

Figure 2.

Cumulative food intake of (A) males and (B) females after ICV administration of SKY2-23-7. Insets represent the cumulative food intake during the first 14 hours postadministration. ${ }^{*} \mathrm{p}<0.05, * * \mathrm{p}<0.01, * * * \mathrm{p}<0.001$. 

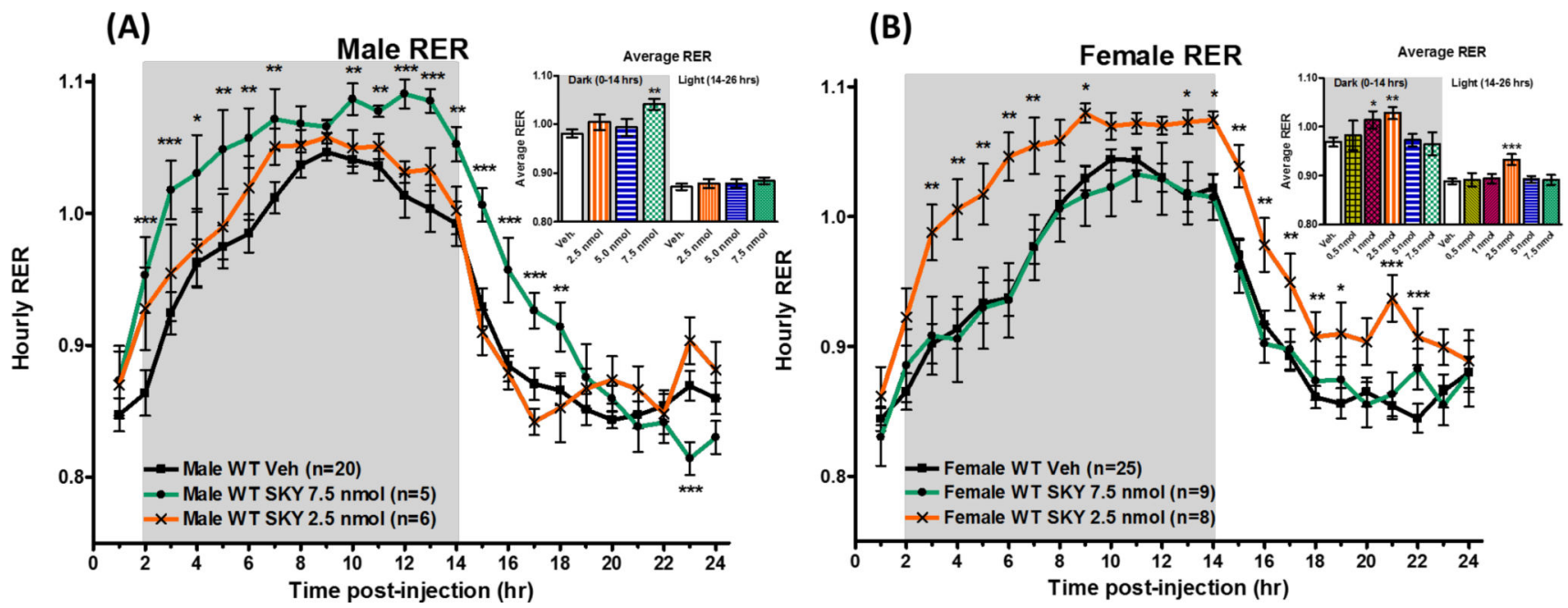

Figure 3.

Average hourly RER values of (A) males and (B) females after ICV admiration of SKY2-23-7. Insets represent the total average RER during the first dark cycle 0-14 hours and the following light cycle 14-26 hours. Full time courses of all doses can be seen in Supplemental Information Figure 1. $* p<0.05, * * p<0.01, * * * p<0.001$. 

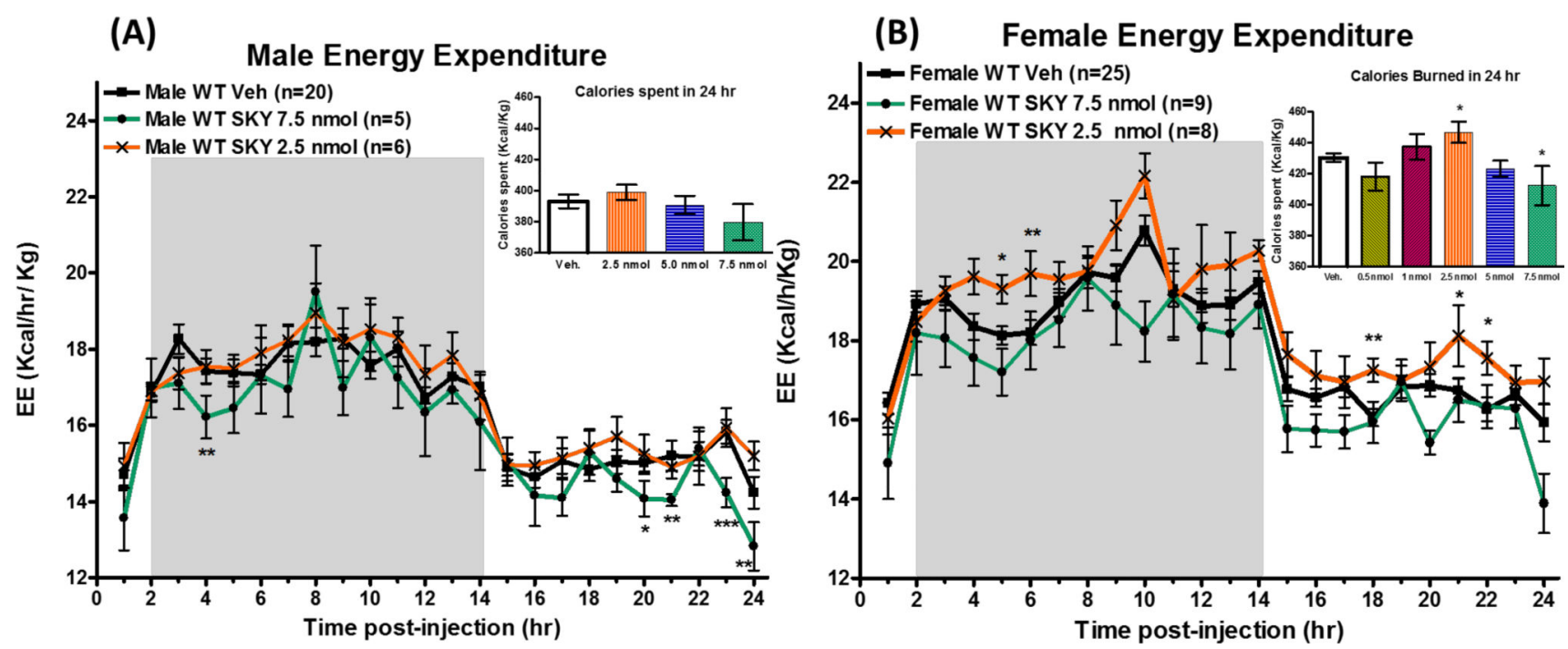

Figure 4.

Average hourly energy expenditure (EE) normalized to body weight (Kcal/hr/Kg) of (A) males and (B) female after ICV admiration of SKY2-23-7. Insets represent the total calories spent during the 24 hour period after administration. Full time courses of all data can be seen in Supplemental Information Figure 2. ${ }^{*} \mathrm{p}<0.05,{ }^{* *} \mathrm{p}<0.01, * * * \mathrm{p}<0.001$. 


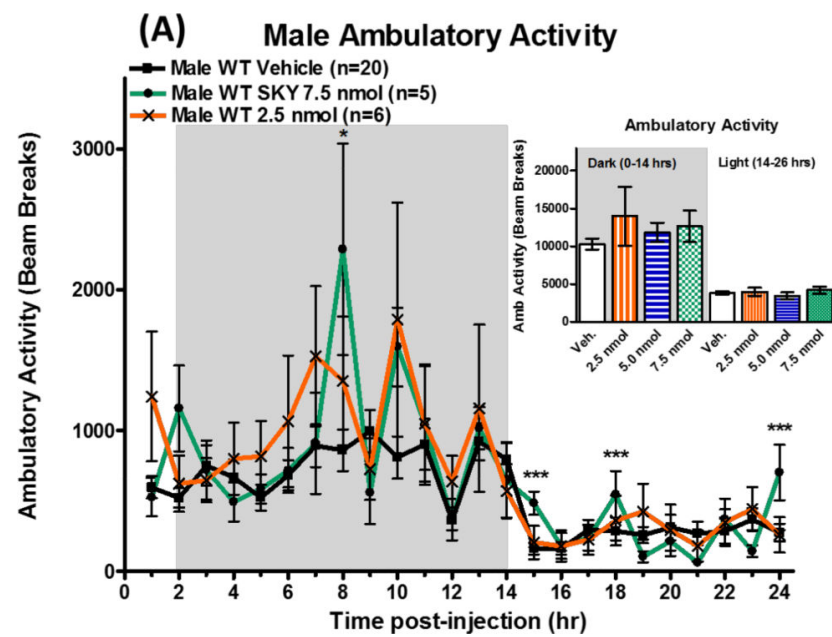

(B) Female Ambulatory Activity

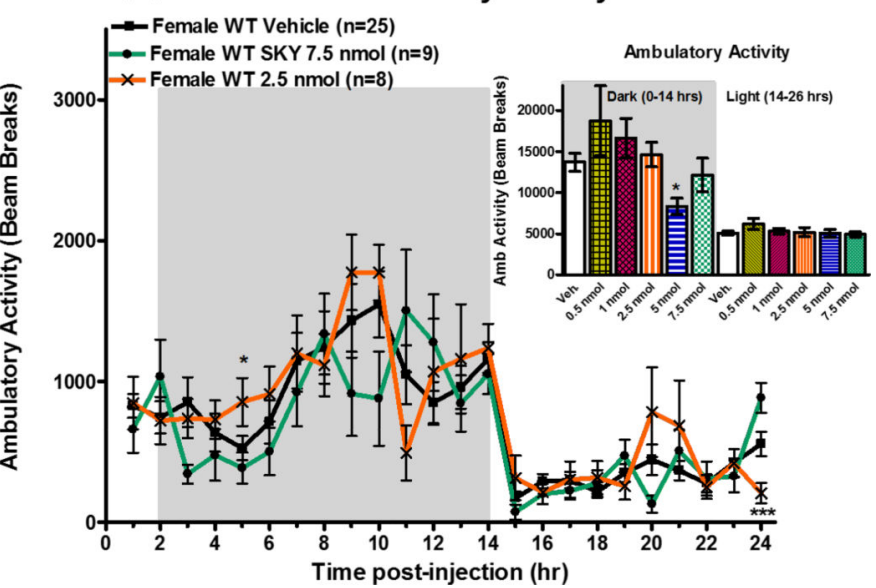

Figure 5.

Average hourly activity of (A) males and (B) females after ICV admiration of SKY2-23-7. Insets represent the total activity (beam breaks) during the first dark cycle 0-14 hours and the following light cycle 14-26 hours. Full time courses of all doses can be seen in Supplemental Information Figure 3. ${ }^{*} \mathrm{p}<0.05,{ }^{*} \mathrm{p}<0.01, * * * \mathrm{p}<0.001$. 


\section{Hypothalamic Gene Expression}

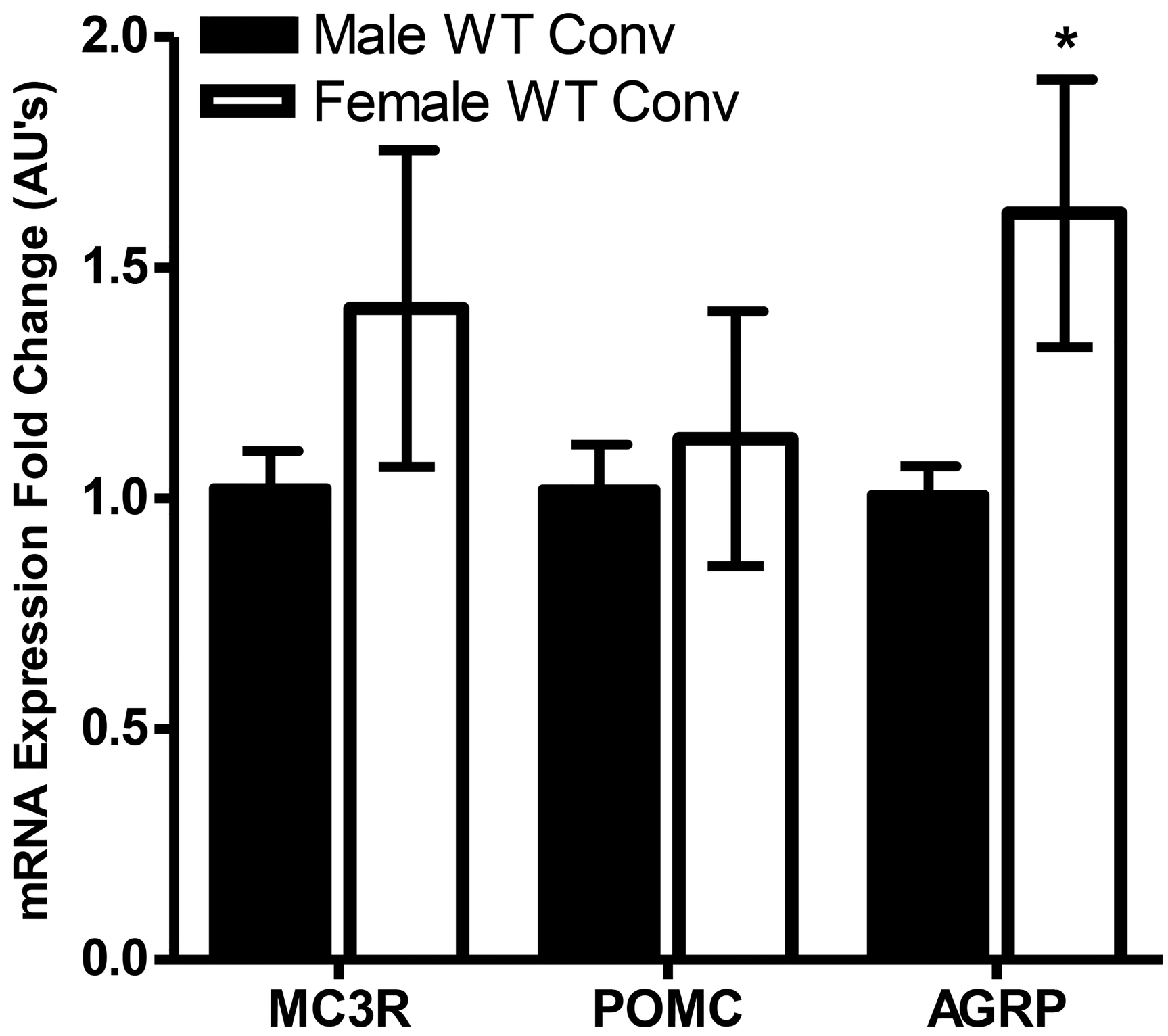

Figure 6.

Hypothalamic gene expression of MC3R, POMC, and AGRP and in male and female wild type mice as analyzed by qRT-PCR. For male MC3R expression $n=8$, and for all other genes $\mathrm{n}=5$. Hypothalamic gene expression was calculated using the $2^{-\Delta \Delta \mathrm{Ct}}$ method and normalized to male expression levels. ${ }^{*} \mathrm{p}<0.05$. 